\title{
The Index of Inclusive Development in Formation of the New Concept of Economic Growth
}

\author{
O.F. Chistik ${ }^{1, *}$ and V.A. Eliseev ${ }^{1}$ \\ "Corresponding author: yurijchistik@yandex.ru \\ ${ }^{1}$ Samara State University of Economics, Samara, Russia
}

\begin{abstract}
The main attention in this article is paid to the global socio-economic and demographic problems which are slowing down the rates of world economic growth. This work reveals the contents of the index of inclusive development and the concept of inclusive growth, their application for development of the human capital and acceleration of rates of growth of world GDP is considered.
\end{abstract}

Keywords: gross domestic product, inclusive growth, inclusive development index, human capital.

\section{Introduction}

In a modern world economic system the main production resource is the human capital. Its qualitative and quantitative characteristics determine the final volume of gross domestic product. As the world population grow there is a problem of effective economic resources distribution for the purpose of development of the human capital as the main driver of modern economy. Therefore, now, more than ever before, there is a need for effective concepts of economic growth focused first of all on the solutions for demographic, social and cultural problems. One of such concepts is the concept of inclusive growth the essence of which consists of even distribution of benefits from economic growth among various participants of economic activity and also in creation of opportunities for inclusion of as much as possible bigger number of interested persons in a process of GDP creation [1]. Until recently practical application of the concept of inclusive growth was interfered by the lack of relevant system of indicators defining efficiency of the activity directed on its implementation. However, the new system of assessment of economic development of the countries was developed. It received the name Inclusive Development Index [2].

\section{Problem Statement}

The problem of economic growth is central in the macroeconomic theory. Many economists were engaged in studying and finding solutions to this problem, however, the ever changing society in general and transforming economic systems in particular today predetermines low efficiency of application of the techniques and approaches developed for the solution of problems of the past. This problem caused a need for search and studying of effective solutions in a fast pace modern world.

Today, the world economy marks the steady economic slowdown trend [3]. Thus, according to information from the World Bank online database during the post-war period 1961-1971 average increase rates of world GDP equaled about 5.4\% a year, but later during the period 2007-2017 this indicator was $2.6 \%$ a year. The world economic system at the present stage of development already implemented the most part of its growth potential. There is a need for development and application of new concepts of economic growth that is transformation of the current structure of market relations for the purpose of new opportunities for economic growth.

\section{Research Questions}

Our research reveals contents of the index of inclusive development and the concept of inclusive growth that gives the chance to estimate the prospects of their application in solution of the social and economic problems caused by demographic changes. In the new concept of economic growth special attention is paid to dynamics of demographic processes as they define qualitative and quantitative characteristics of the human capital. Studying demographic problems in various regions of the world allows investigating interrelation between demographic processes and rates of world economic growth. That gives necessary information for development of solutions capable to accelerate growth rates of world GDP. 


\section{Purpose of the Study}

Our goal in this article is based on the research of dynamics of demographic indicators to determine relationship between demographic processes and global social and economic problems. At the same time we give an assessment of the index of inclusive development application in the new concept aimed at the development of the human capital and achievement of steady rates of economic growth.

\section{Research Methods}

The starting point of a research is the analysis of demographic changes in developed and developing countries of the world. Information basis for studying demographic processes is statistical data of various international organizations and publications in the scientific press. In this research general scientific methods of knowledge were applied: dialectic method of knowledge, logical-theoretical analysis, synthesis and analysis, generalization and system approach. We also used a wide arsenal of reliable statistical methods such as: a method of multidimensional statistical grouping, a method of generalizing indicators, a method of the time series analysis of indicators and an index method. The research reveals contents of the index of inclusive development and the concept of inclusive growth that gives the opportunity to assess the prospects of their application in the solution of the social and economic problems caused by demographic changes as well as changing rates of world economy growth.

\section{Findings}

\subsection{Modern global social and economic problems}

For the last few decades decrease in rates of world economy growth was matched by increasing inequality in income and accumulated wealth among world's population [4]. There are bases to believe that the system of income distribution affects not only stability of society, but growth rates of world economy as well. Aggravation of economic inequality leads to access restriction to education for lower-income population strata that has negative impact on development of the human capital as a main resource of a modern economic system [5]. Moreover, according to several researches, reduction in income differentiation between poor and rich groups of the population promote significant acceleration of rates of world economic growth [6,7]. The problem of the growing inequality in income and accumulated wealth among world's population is closely related to demographic processes which happen in the developing and developed countries.

Today the steady trend of decrease in rates of natural population growth in the developed countries is observed. It confirms the oncoming demographic crisis in a number of countries. Thus, according to forecasts of United Nations Department of Economic and Social Affairs natural increase of the cumulative population of the most developed regions (Europe, North America, Australia/New Zealand and Japan) will continue to decrease up to the period of 20252030 when the indicator of natural increase takes negative value and will mark the beginning of depopulation [8]. Longterm decrease in rates of natural population growth combined with high standard of living and the growing indicator of life expectancy at birth triggers changes in population age structure, as a result it leads to increased demographic pension expenditure burden on the population of working-age (Tables 1,2,3).

Table 1. The rates of natural population growth in regions of the world calculated on the basis of information from the UNDESA (1985-2030)

\begin{tabular}{|l|c|c|c|c|c|c|c|c|c|}
\hline \multirow{2}{*}{ Regions or area } & \multicolumn{6}{|c|}{ Rate of natural population growth (per 1,000 population) } \\
\cline { 2 - 10 } & $\begin{array}{c}\mathbf{1 9 8 5 -} \\
\mathbf{1 9 9 0}\end{array}$ & $\begin{array}{c}\mathbf{1 9 9 0 -} \\
\mathbf{1 9 9 5}\end{array}$ & $\begin{array}{c}\mathbf{1 9 9 5} \mathbf{2 0 0 0} \\
\mathbf{2 0 0 0}\end{array}$ & $\begin{array}{c}\mathbf{2 0 0 5}- \\
\mathbf{2 0 1 0}\end{array}$ & $\begin{array}{c}\mathbf{2 0 1 0} \\
\mathbf{2 0 1 5}\end{array}$ & $\begin{array}{c}\mathbf{2 0 1 5} \\
\mathbf{2 0 2 0}\end{array}$ & $\begin{array}{c}\mathbf{2 0 2 0}- \\
\mathbf{2 0 2 5}\end{array}$ & $\begin{array}{c}\mathbf{2 0 2 5}- \\
\mathbf{2 0 3 0}\end{array}$ \\
\hline $\begin{array}{l}\text { More developed } \\
\text { regions }\end{array}$ & 4,2 & 2,3 & 1,0 & 0,7 & 1,3 & 1,1 & 0,6 & 0,1 & $-0,5$ \\
\hline $\begin{array}{l}\text { Less developed } \\
\text { regions }\end{array}$ & 21,8 & 18,6 & 16,3 & 15,3 & 14,8 & 14,1 & 12,9 & 11,6 & 10,4 \\
\hline $\begin{array}{l}\text { Least developed } \\
\text { countries }\end{array}$ & 28,1 & 26,8 & 26,6 & 26,3 & 26,0 & 25,2 & 24,2 & 23,0 & 21,8 \\
\hline
\end{tabular}

Source: compiled by the authors.

Meanwhile, in less developed and the least developed regions of the world (Africa, Asia except Japan, Latin America and the Caribbean plus Melanesia, Micronesia and Polynesia as defined by the United Nations General Assembly) it is possible to observe quite different processes. In less developed countries with the low and average levels of income usually high rates of natural growth of population is accompanied with low standard of living and a weak health care system [8]. The indicator of life expectancy at birth in such states is much lower than in the developed countries. It implies specific changes of age structure of the population and increase in child demographic burden on a working-age population (Table 1,2,4). The majority population of such regions are young people of working-age. When 
a national economy is not able to provide high employment and a decent standard of living for citizens they tend to migrate for search of better conditions for life and self-realization.

The contrasting differences of demographic processes in developed and developing countries added to increasing economic inequality within the last three decades has led to growth of international migration in absolute and relative numbers to the total population of the planet [9]. International migration is a complex phenomenon which directly influences process of human capital formation and can render both positive and negative impact on national economic systems. International migration may partially contribute to the solution of the problem of economic inequality, as it positively influences the income of immigrants.

Table2. Life expectancy at birth in regions of the world calculated on the basis of information from the UNDESA (1985-2030)

\begin{tabular}{|l|c|c|c|c|c|c|c|c|c|}
\hline \multirow{2}{*}{ Regions or area } & \multicolumn{6}{|c|}{ Life expectancy at birth for both sexes combined (years) } \\
\cline { 2 - 10 } & $\begin{array}{c}\mathbf{1 9 8 5}- \\
\mathbf{1 9 9 0}\end{array}$ & $\begin{array}{c}\mathbf{1 9 9 0 -} \\
\mathbf{1 9 9 5}\end{array}$ & $\begin{array}{c}\mathbf{1 9 9 5} \mathbf{2 0 0 0} \\
\mathbf{2 0 0 0}\end{array}$ & $\begin{array}{c}\mathbf{2 0 0 5}- \\
\mathbf{2 0 0 5}\end{array}$ & $\begin{array}{c}\mathbf{2 0 1 0} \\
\mathbf{2 0 1 5}\end{array}$ & $\begin{array}{c}\mathbf{2 0 1 5} \mathbf{2 0 2 0} \\
\mathbf{2 0 2 0}-\end{array}$ & $\begin{array}{c}\mathbf{2 0 2 5}- \\
\mathbf{2 0 2 5}\end{array}$ \\
\hline $\begin{array}{l}\text { More developed } \\
\text { regions: }\end{array}$ & 73,94 & 74,16 & 74,80 & 75,59 & 76,93 & 78,43 & 79,28 & 80,12 & 80,93 \\
\hline $\begin{array}{l}\text { Less developed } \\
\text { regions }\end{array}$ & 61,32 & 62,52 & 63,78 & 65,47 & 67,36 & 69,10 & 70,34 & 71,39 & 72,37 \\
\hline $\begin{array}{l}\text { Least developed } \\
\text { countries }\end{array}$ & 50,64 & 51,54 & 53,81 & 56,43 & 59,84 & 62,66 & 64,57 & 66,10 & 67,50 \\
\hline
\end{tabular}

Source: compiled by the authors.

Table 3. The pension demographic burden in most developed regions of the world calculated on the basis of information from the UN DESA (1985-2025)

Source: compiled by the authors.

\begin{tabular}{|l|c|c|c|c|c|c|c|c|c|}
\hline \multirow{2}{*}{ Regions or area } & \multicolumn{8}{|c|}{ Old-age dependency ratio } \\
\cline { 2 - 10 } & $\mathbf{1 9 8 5}$ & $\mathbf{1 9 9 0}$ & $\mathbf{1 9 9 5}$ & $\mathbf{2 0 0 0}$ & $\mathbf{2 0 0 5}$ & $\mathbf{2 0 1 0}$ & $\mathbf{2 0 1 5}$ & $\mathbf{2 0 2 0}$ & $\mathbf{2 0 2 5}$ \\
\hline $\begin{array}{l}\text { More developed } \\
\text { regions }\end{array}$ & 17,5 & 18,7 & 20,4 & 21,2 & 22,6 & 23,7 & 26,7 & 30,2 & 33,8 \\
\hline
\end{tabular}

Table 4. The child demographic burden in regions of the world calculated on the basis of information from the UN DESA (1985-2025)

\begin{tabular}{|l|r|r|r|r|r|r|r|r|r|}
\hline \multirow{2}{*}{ Region or area } & \multicolumn{7}{|c|}{ Child dependency ratio } \\
\cline { 2 - 10 } & $\mathbf{1 9 8 5}$ & $\mathbf{1 9 9 0}$ & $\mathbf{1 9 9 5}$ & $\mathbf{2 0 0 0}$ & $\mathbf{2 0 0 5}$ & $\mathbf{2 0 1 0}$ & $\mathbf{2 0 1 5}$ & $\mathbf{2 0 2 0}$ & $\mathbf{2 0 2 5}$ \\
\hline $\begin{array}{l}\text { Less developed } \\
\text { regions }\end{array}$ & 64,3 & 61,1 & 57,8 & 53,1 & 47,7 & 44,5 & 43,0 & 41,7 & 40,1 \\
\hline $\begin{array}{l}\text { Least developed } \\
\text { countries }\end{array}$ & 86,3 & 85,6 & 83,0 & 80,2 & 77,5 & 75,1 & 71,3 & 67,1 & 63,2 \\
\hline
\end{tabular}

Source: compiled by the authors.

Besides, the international migration somewhat reduces a gap between developed and developing countries. For example, immigrants make money transfers from the countries with high level of income to the countries with average and low levels of income. However, uncontrollable immigration and emigration flows have a negative impact on national economic systems. They contribute to the oversaturation of the labor market and generally increase the social burden in host countries. Also they cause deficiency of human resources in countries of emigrants' origin and increase of economic dependence of those countries on external factors. Besides, powerful migration processes create favorable conditions for criminal activity and international terrorism [9].

Today the world community has to apply new approaches to the problem of economic growth in order to achieve acceleration of economic development and find solutions to global social and economic problems. One of those can be the inclusive approach, which is the cornerstone of the concept of inclusive growth. It is impossible to create and implement a new concept of economic growth targeted for increase of GDP rates through the solution of social problems without methodological and statistical base. The new system of social and economic development level assessment of the state which received the name Inclusive Development Index can take this place.

\subsection{Prospects of the index of inclusive development application}

The main objective of the index of inclusive development is broad disclosure of economic information about the state to all interested persons and the public for the benefit of economic development of the country. This index is calculated on the basis of 12 indicators divided in three groups (Growth and Development; Inclusion; Intergenerational Equity and Sustainability), each of which reflects various aspects of social life [2]. The index of inclusive development initially was developed within the concept of inclusive growth, however, it can find application outside the separate concept. 
When forming with the subsequent implementation the new concept of economic growth directed specifically to GDP growth rates increase through the solution of social and economic problems, application of this index can be in high demand. As the system of assessment of social and economic level of development of the country, the index of inclusive development gives the most comprehensive information on a state of national economic system as well as society in general. Some common and widely accepted indicators of economic development of the country such as GDP can not provide full information for working out effective policy of the state. No doubt, GDP is the most widely used indicator of economic development of the state, the convenient instrument for accounting the size of economy today. However, it is incorrect to use GDP as the main reference point while planning social and economic development policy of the country at present, because GDP indicator for the purpose has a number of restrictions.

As GDP indicator measures economy size is does not always adequately reflect quantitative characteristics of a modern economic system. Scientific and technical progress contributed to creation of essentially new types of goods and services and to substantial enhancement of ways of information and resources exchange. Using the existing methods of collecting statistics it is getting increasingly harder to account for some specific transactions or to carry out financial assessment of new types of economic activity. As an example, consider the market of crypto currencies which is difficult to account and regulate. Another example is investment accounting for intangible assets becoming more and more relevant today. In modern economy long-term investments in such valuable resources as information, knowledge, scientific R\&D and human capital can hardly be fully reflected in GDP. As an indicator of social and economic level of development of the country GDP also has certain restrictions. It does not measure the system of product distribution, therefore GDP can not be used as a measure of country's prosperity. Besides, GDP does not fully measure ecological and social factors of economic growth.

The essence of the earlier stated boils down to the idea that GDP can not be effectively used to adequately estimate the level of social and economic development of the modern state, as it does not reflect the influence of non-economic factors on an economic system and society in general. On the opposite, the index of inclusive development provides complex information on various aspects of society. In the long term perspective this index can be used in forecasting of social and economic development of the state. Active application of a new system of assessment of economic development by the international community will promote changes in the social and economic policy of states, stimulate international economic integration and development of methodological base of national and international statistical institutions. Taken together, the index of inclusive development opens new opportunities for working out, development and implementation of new concepts of economic growth, such as inclusive growth, sustained economic growth, social and economic problem solution in developed and developing countries.

\section{Conclusion}

As a result of our research it was established that decrease in growth rates of world GDP is connected with exacerbation of economic inequality which is in turn closely interconnected with demographic processes. Rates of natural population growth in the most developed regions of the world decreased during the period 1985-2015, and according to forecasts of UN DESA by 2030 will take a negative value. Rates of natural growth of population in less developed regions of the world with low and average levels of income are times higher, than in the most developed regions. Thus, demographic changes in various regions of the world together with socio-economic factors contribute to the annual growth of international migration which may render both positive and negative impact on rates of world economic growth. We suggest a new concept of economic growth as a solution for global social and economic problems and acceleration of growth rates of world GDP. It is aimed at the qualitative development of the human capital, social problems solution and progressive social development. The index of inclusive development serves as a basis for the new concept of inclusive growth, which in turn is a new system of social and economic development level evaluation. Widespread use of the index of inclusive development will contribute to development and implementation of the new concept of economic growth, effective social and economic policy-making in specific countries and acceleration of rates of world economic growth.

\section{References}

1. C. Deeming, P. Smyth., Social investment, inclusive growth that is sustainable and the new global social policy. In C. Deeming \& P. Smyth (Eds.), Reframing global social policy: Social investment for sustainable and inclusive growth, (pp. 11-44). Policy Press: Bristol (2017).

2. The inclusive growth and development report 2017, The Report presents a new global index, the Inclusive Development Index (World Economic Forum). Retrieved from: https://www.weforum.org/reports/the-inclusivegrowth-and-development-report-2017. Accessed: 30.12 .2018 (2017).

3. A.V. Avakov, Two thousand years of economic statistics, years 1 - 2012: population, GDP at PPP, and GDP per capita, volume 1, by rank. New York, NY: Algora Publishing (2015).

4. G.A. Marrero, J.G. Rodríguez, Inequality of opportunity and growth. Journal of Development Economics, 104, 107122. DOI: 10.1016/j.jdeveco.2013.05.004 (2013).

5. A. Mason, R. Lee, J.X. Jiang, Demographic dividends, human capital, and saving. The Journal of the Economics of Ageing, 7, 106-122. DOI: 10.1016/j.jeoa.2016.02.004 (2016). 
6. E. Dabla-Norris, K. Kochhar, N. Suphaphiphat, F. Ricka, E. Tsounta, Causes and consequences of income inequality: A global perspective (IMF Staff discussion note No. 15/13). Washington, DC: International Monetary Fund (2015).

7. A.K. Fosu, Growth, inequality, and poverty reduction in developing countries: Recent global evidence. Research in Economics, 71(2), 306-336. DOI: 10.1016/j.rie.2016.05.005 (2017).

8. World Population Prospects: The 2017 Revision, The World Population Prospects: The 2017 Revision provides a comprehensive review of global demographic trends and prospects for the future (UN Department of Economic and Social Affairs). Retrieved from: https://www.un.org/development/desa/publications/world-population-prospects-the2017-revision.html. Accessed: 30.12.2018 (2017).

9. International Organization for Migration, World migration report 2018. Retrieved from: https://publications.iom.int/books/world-migration-report-2018. Accessed: 30.12 .2018 (2017). 